\title{
Data Collection
}

\begin{tabular}{|c|c|}
\hline Source & 22ID \\
\hline Space group & C121 \\
\hline \multicolumn{2}{|l|}{ Cell dimensions: } \\
\hline $\mathrm{a}, \mathrm{b}, \mathrm{c}(\AA)$ & $227.0,49.3,92.9$ \\
\hline$\alpha, \beta, y\left({ }^{\circ}\right)$ & $90.0,94.8,90.0$ \\
\hline Resolution $(\AA ̊)$ & $20-2.55(2.64-2.55)$ \\
\hline$R_{\text {merge }}$ & $0.09(0.44)$ \\
\hline$|/ \sigma|$ & $11.7(2.0)$ \\
\hline Completeness (\%) & $95.1(83.3)$ \\
\hline Redundancy & $3.8(2.9)$ \\
\hline \multicolumn{2}{|l|}{ Refinement } \\
\hline Resolution ( $\AA$ ) & $20-2.56$ \\
\hline No. reflections & 31,818 \\
\hline$R_{\text {work }} / R_{\text {free }}$ & $0.23 / 0.27$ \\
\hline \multicolumn{2}{|l|}{ No. atoms: } \\
\hline Protein & 6603 \\
\hline Water & 12 \\
\hline \multicolumn{2}{|l|}{ B-factors: } \\
\hline Protein & 47.9 \\
\hline Water & 23.1 \\
\hline \multicolumn{2}{|l|}{ RMSD from ideality: } \\
\hline Bond length $(\AA)$ & 0.009 \\
\hline Bond angle $\left(^{\circ}\right)$ & 1.151 \\
\hline \multicolumn{2}{|l|}{ Ramachandran plot: } \\
\hline Favored & $98 \%$ \\
\hline Allowed & $99 \%$ \\
\hline PDB entry & 4L3E \\
\hline
\end{tabular}

Table S2. X-ray data collection and refinement statistics for the crystal structure of the DMF5 aD26Y/BL98W - ELA/HLA-A2 complex. 